\title{
PENGARUH STRATEGI PEMBELAJARAN INKUIRI TERHADAP KEMAMPUAN SAINS ANAK KELOMPOK B DI RA DARUL FAZRI DESA LAUT DENDANG T.A 2018/2019
}

\author{
Salpina \\ Universitas Islam Negeri Sumatera Utara Medan \\ E-mail: salpinasimahate@gmail.com \\ Khadijah \\ Universitas Islam Negeri Sumatera Utara Medan \\ E-mail:khadijah@gmail.com \\ Zulfahmi Lubis \\ Universitas Islam Negeri Sumatera Utara Medan \\ E-mail: zulfahmi@gmail.com
}

Article received: 31 Juli 2019, Review process: 05 Agustus 2019

Article published: 30 September 2019

\begin{abstract}
This study aims to find: (1) Children's Science Ability (2) Science Ability Children use inquiry learning strategies (3) Significant influence of inquiry learning strategies on children's scientific abilities in RA. Darul Fazri T.A. 2018/2019. The type of research conducted is experimental research with a quantitative approach. The results showed that Inquiry learning strategies influenced the scientific ability of group $B$ children. This was base on the results of the research in the experimental class, obtained results of children's scientific abilities with an average score of pre-test 4 and posttest 9 average scores with scores the highest post-test 12 and the lowest value 4 so that the scientific ability of children in the experimental class is better than the control class. The scientific abilities of children in the control class get an average score of 4.3 tests and an average post-test of 5.8 with the highest score of 10 and the lowest value of 4 . This is also based on the results of hypothesis testing, namely $t_{\text {count }}>t_{\text {table }}$ and the results obtained testing is 4.38>2.047 with a significant number of $\alpha=0.05$. Thus the hypothesis Ho is rejecting and $\mathrm{Ha}$ is accept so that it can being stated that there is a significant effect of Inquiry Learning Strategy on the Science Ability of Group B Children Aged 5-6.
\end{abstract}

Keywords: Inquiry Learning Strategy, Science Ability

Abstrak
Penelitian ini bertujuan untuk mengetahui: (1) Kemampuan Sains Anak (2)
Kemampuan Sains Anak menggunakan strategi pembelajaran Inkuiri (3) Pengaruh 
yang signifikan strategi pembelajarn Inkuiri terhadap kemampuan sains anak di RA. Darul Fazri T.A. 2018/2019. Jenis penelitian yang dilakukan adalah penelitian eksperimen dengan pendekatan kuantitatif. Hasil penelitian menunjukkan bahwa strategi pembelajaran Inkuiri berpengaruh terhadap kemampuan sains anak kelompok B. Hal ini berdasarkan dari hasil penelitian di kelas eksperimen, diperoleh hasil kemampuan sains anak dengan skor rata-rata pre-test 4 dan skor rata-rata post-test 9 dengan nilai tertinggi post-test 12 dan nilai terendah 4 sehingga kemampuan sains anak dikelas eksperimen lebih baik dari kelas kontrol. Adapun kemampuan sains anak dikelas kontrol mendapakan skor rata-rata pre test 4,3 dan rata-rata post-test 5,8 dengan nilai tertinggi 10 dan nilai terendah 4 . Hal ini juga berdasarkan hasil pengujian hipotesis, yaitu $t_{\text {hitung }}>t_{\text {tabel }}$ dan diperoleh hasil pengujian yaitu 4,38>2,047 dengan angka signifikan sebesar $\alpha=0,05$. Dengan demikian hipotesis Ho ditolak dan Ha diterima sehingga dapat dinyatakan ada pengaruh yang signifikan dari Strategi Pembelajaran Inkuiri terhadap Kemampuan Sains Anak Kelompok B Usia 5-6 tahun.

Kata Kunci : Strategi Pembelajaran Inkuiri, Kemampuan Sains

\section{PENDAHULUAN}

Peraturan menteri Pendidikan dan Kebudayaan Republik Indonesia Nomor 137 Tahun 2014 tentang Standar Nasional Pendidikan Anak Usia Dini bab III pasal 7 butir 3, menjelaskan bahwa terdapat enam aspek tingkat pencapaian perkembangan anak yakni 1) Nilai agama dan moral; 2) Fisik-Motorik; 3) Kognitif; 4) Bahasa; 5) Sosial-emosional; dan 6) Seni.

Salah satu aspek perkembangan yang sangat penting untuk dikembangkan dan diberikan stimulus pada anak usia dini yakni aspek perkembangan kognitif. Kognitif merupakan segala sesuatu yang berkaitan dengan proses berpikir. Kognitif adalah kemampuan untuk mempelajari keterampilan dan konsep baru, keterampilan untuk memahami apa yang terjadi dilingkungannya, serta keterampilan menggunakan daya ingat dan menyeselasikan soal-soal sederhana. Bidang pengembangan kognitif anak usia dini terdiri dari beberapa pengembangan dasar, salah satunya adalah pengembangan sains.

Menuut Khadijah (2016:31) hakikat pengembangan sains di TK adalah kegiatan belajar sambil bermain yang menyenangkan dan menarik melalui pengamatan, penyelidikan dan percobaan untuk mencari tahu atau menemukan jawaban tentang segala sesuatu yang ada didunia sekitar.

Terkait kayanya manfaat dari pembelajaran sains untuk anak, diantaranya yaitu mampu memupuk rasa percaya diri anak di dalam lingkunganya, memberikan pengalaman penting secara langsung pada anak, mengembangkan konsep dasar pengetahuan alam, 
meningkatkan kemampuan mengamati, memperoleh kesempatan untuk menggunakan material yang biasa digunakan dalam pembelajaran sains, sehingga anak mulai terbiasa sejak dini, memperoleh bantuan dalam memecahkan masalah, mendapatkan kesempatan untuk bereksplorasi, mengembangkan kemampuan berbahasa melalui penambahahan kosakata ketika anak melakukan kegiatan menanya dan menjawab pertanyaan, mengembangkan kemampuan sensori, fisik, intelektual, emosional, spiritual, dan sosial, serta mendapat kesempatan untuk menstimulasikan rasa keingintahuan mereka (Mirawati dan Nugraha, 217). Karena anak memiliki rasa ingin tahu yang sangat tinggi, dengan rasa ingin tahu yang dimiliki anak telah membangun konsep sains dalam dirinya. Pengenalan sains untuk anak dengan cara membuat anak belajar bereksperimen, berkeskplorasi dan menyelidiki lingkungan sekitarnya sehingga anak membangun suatu pengetahuan yang nantinya dapat berguna pada masa dewasa (Hafisah,2017).

Berdasarkan bidang pengembangan atau target kemampuan, sains terbagi menjadi tiga, yaitu: penguasaan produk sains, penguasaan proses sains dan penguasaan sikap sains. Maisarah (2018:26) menyatakan bahwa unsur utama yang terdapat dalam sains atau IPA yaitu sikap manusia, proses, dan produk yang satu sama lain tidak dapat dipisahkan. Rasa ingin tahu pada masalah yang terjadi di alam merupakan sikap manusia, manusia kemudian mencoba memecahkan masalah yang dihadapinya, pada tahapan digunakan proses atau metode dengan cara menyusun hipotesis, melakukan kegiatan untuk membuktikan kebenaran hipotesisnya, dan mengevaluasi apa yang telah dilakukannya. Hasil atau produk dari kegiatan yang telah dilakukannya tersebut berupa fakta-fakta, prinsip-prinsip, atau teori-teori.

Dalam pembelajaran sains pada anak, proses merupakan suatu yang penting, karena proses memperoleh pengetahuan dan informasi sains itulah yang akan melahirkan pengalaman belajar. Adapun penguasaan proses sains meliputi kemampuan: mengamati (observasi), mengklasifikasikan (menggolongkan), meramalkan (memprediksi), menyimpulkan (inference), mengkomunikasikan, penggunaan alat dan pengukuran, merencanakan penelitian, dan menerapkan (Nugraha, 2008: 98).

Hal ini sejalan dengan tujuan khusus pengembangan sains di TK yakni agar anak memiliki kemampuan mengamati berbagai perubahan yang terjadi, melakukan percobaan sederhana, melakukan kegiatan mengklasifikasi, membandingkan, memperkirakan, dan mengkomunikasikannya serta membangun kreativitas dan inovasi pada diri anak (Khadijah, 2016:54). 
Akan tetapi pada kenyataanya, berdasarkan hasil observasi yang dilakukan, di RA Darul Fazri Laut Dendang pada kelompok usia 5-6 tahun yang berjumlah 16 anak, 11 anak laki-laki dan 5 anak perempuan, masih banyak anak yang memiliki kemampuan sains belum berkembang. Hal ini terlihat dari beberapa anak yang memiliki kemampuan sains dalam penguasaan proses sains pada aspek 1) Kemampuan mengamati terdapat 5 anak; 2) Mengklasifikasikan (menggolongkan) terdapat 1 orang anak; dan 3) Mengkomunikasikan terdapat 2 orang anak; serta 4) Penggunaan alat dan pengukuran terdapat 4 orang anak. Hal ini terlihat yakni pada saat pembelajaran, proses belajar hanya fokus pada buku kreativitas anak atau yang disebut dengan majalah anak, sehingga pemahaman anak tentang proses sains hanya sebatas teori bukan mengalami langsung proses sains tersebut.

Berdasarkan hasil pengamatan menunjukkan bahwa dalam proses pembelajaran, guru sudah memberikan pembelajaran yang cukup baik, akan tetapi masih terdapat beberapa kekurangan dalam proses pembelajaran sains, diantaranya yaitu kurangnya strategi pembelajaran yang bervariatif, pembelajaran sains masih disajikan melalui kegiatan ceramah dan pemberian tugas seperti kegiatan menulis, berhitung, menggambar, dan mewarnai, kurang memerankan anak dalam proses pembelajaran sains, serta kecenderungan guru masih menggunakan strategi yang berpusat pada guru dalam proses pembelajran. Selain itu, masih kurangnya penggunaan media sebagai alat bantu dalam proses pembelajaran. Hal ini terlihat karena guru masih menggunakan papan tulis dan media berbentuk gambar pada proses pembelajaran sains. Rendahnya kemampuan sains anak tentunya akan berakibat pada perkembangan kognitif anak, kemampuan berpikir kritis dan kreatif.

Guru berperan penting dalam pengembangan kemampuan sains anak, untuk meningkatkan kemampuan sains anak dapat dilakukan dengan menggunakan media pembelajaran yang menarik, selain itu sebaiknya guru menggunakan strategi pembelajaran yang melibatkan keaktifan anak sebagai pelaku pembelajaran yang berpusat pada anak, dan peran guru sebagai fasilitator dan motivator.

Khadijah (2015: 145-146) menyatakan bahwa salah satu komponen terpenting untuk mencapai keberhasilan pendidikan dalam mencapai tujuan adalah ketepatan menentukan strategi pembelajaran. Karena strategi merupakan a plan of operation achieving something (rencana kegiatan untuk mencapai sesuatu). Kemudian Rohani (2016: 239) menyebutksn ada beberapa jenis strategi yang dapat digunakan dalam pembelajaran sains, diantaranya yaitu kegiatan eksplatorasi (explatory activities), penemuan terbimbing (guided discovey), 
pemecahan masalah (problem solving), diskusi (discussion), belajar kooperatif (cooperative learning), demonstrasi (demonstration), dan pengajaran langsung (direct intruction). Dalam buku Masganti juga dijelaskan beberapa strategi yang dapat digunakan untuk pembelajaran sains yaitu strategi pembelajaran inkuiri, strategi pembelajaran tematik berbasis discovery, dan strategi pembelajaran berbasis masalah (Masganti, Dkk, 2016: 49-56). Adapun salah satu strategi pembelajaran yang diharapkan dapat mengembangkan kemampuan sains anak serta yang akan digunakan dalam penelitian ini adalah strategi pembelajaran inkuiri

Hal ini berdasarkan hasil penelitian Reni Devita Sari dan Sri Joeda Andajani (2017), yang menyatakan bahwa strategi inkuiri dapat mempengaruhi kemampuan sains anak, terlihat dari hasil akhir kemampuan sains anak meningkat dari sebelumnya tanpa menggunakan strategi inkuiri.

Sejalan dengan hasil penelitian diatas, penelitian Schlenker dalam Masganti juga menyatakan bahwa inkuiri dapat meningkatkan pemahaman sains, produktif dalam berpikir kreatif, dan siswi menjadi terampil dalam memperoleh dan menganalisis informasi. Hal ini disebabkan karena strategi pembelajaran inkuiri berbeda dengan strategi pembelajaran lainnya, perbedaan tersebut dapat dilihat dari proses pembelajarannya yang mengharuskan anak mengolah pesan untuk mendapatkan pengetahuan, keterampilan, dan nilai-nilai. Didalam strategi pembelajaran inkuiri anak dirancang untuk terlibat dalam melakukan panggilan informasi (inquiry). Ciri khas dari strategi pembelajaran inkuiri ini adalah bentuk pembelajaran yang berpusat pada siswa (student centered) (Masganti, Dkk, 2016:49).

Berdasarkan latar belakang masalah diatas yaitu lemahnya kemampuan sains anak, maka peneliti tertarik untuk melakukan penelitian tentang strategi pembelajaran inkuiri dan kemampuan sains anak di RA Darul Fazri dengan harapan setelah diterapkannya strategi pembelajaran tersebut kemampuan sains peserta didik semakin meningkat maka peneliti mengangkat judul penelitian: "Pengaruh Strategi Pembelajaran Inkuiri Terhadap Kemampuan Sains Anak Kelompok Usia 5-6 Tahun di RA Darul Fazri DesaLaut Dendang”.

Berdasarkan uraian di atas, maka dirumuskan beberapa masalah yaitu: (1) Bagaimana kemampuan sains anak kelompok B dengan menggunakan strtaegi pembelajaran Inkuiri?; (2) Bagaimana kemampuan sains anak kelompok B dengan menggunakan strategi pembelajaran Ekspositori? dan (3) Apakah terdapat pengaruh strategi pembelajaran Inkuiri terhadap kemampuan sains anak kelompok B di RA Darul Fazri Desa Laut Dendang?

\section{METODOLOGI}


Penelitian ini menggunakan jenis penelitian Quasi Eksperimental. Quasi Eksperimental Desain mempunyai kelompok kontrol, tetapi tidak dapat berfungsi sepenuhnya mengontrol variabel-variabel luar yang mempengaruhi pelaksanaan eksperimen (Sugiyono, 2013: 115-116). Desain yang digunakan adalah Post-Test kontrol Grup Desain (Non Equevalent Control Group Design) yang diteliti dalam 2 kelas dan mempunyai dua kelompok, yaitu kelompok eksperimen yang akan menggunakan strategi pembelajaran Inkuiri dan kelompok kontrol yang tidak menggunakan strategi pembelajaran Inkuiri atau menggunakan strategi pembelajaran Ekspositori.

Tabel Desain Eksperimen dan kontrol

\begin{tabular}{|l|c|c|c|}
\hline \multicolumn{1}{|c|}{ Kelas } & Pre Test & Treatment & Post Test \\
\hline Eksperimen & $\mathrm{O}_{1}$ & $\mathrm{X}$ & $\mathrm{O}_{2}$ \\
\hline Kontrol & $\mathrm{O}_{3}$ & - & $\mathrm{O}_{4}$ \\
\hline
\end{tabular}

Keterangan:

$\mathrm{O}_{1}$ : Observasi awal menggunakan strategi inkuiri

$\mathrm{O}_{2}:$ Observasi setelah menggunakan strategi inkuiri

$\mathrm{X}$ : Kelas eksperimen yang diperikan perlakuan menggunakan strategi inkuiri

$\mathrm{O}_{3}$ : Observasi awal kelas kontrol tidak menggunakan strategi inkuiri

$\mathrm{O}_{4}$ : Observasi setelah kelas kontrol tidak menggunakan strategi inkuiri

Menurut Indra Jaya (2018:20) Populasi adalah wilayah generalisasi yang terdiri atas objek/subjek yang memiliki kuantitas dan karakteristik tertentu yang diterapkan oleh peneliti untuk dipelajari dan kemudian ditarik kesimpulannya. Sampel adalah sebahagian dari jumlah dan karakteristik yang dimiliki oleh populasi tersebut (Indra Jaya, 2018:32). Sesuai dengan judul penelitian, maka yang menjadi populasi pada penelitian ini yaitu: anak usia dini kelompok B (5-6 tahun) di RA Darul Fazri yang berjumlah 49 anak dan terdistribusi pada dua kelas, yaitu: kelas Umar, kelas Ali dan kelas Siddiq. Penarikan sampel pada penelitian ini menggunakan teknik Cluster Random Sampling, yang dilakukan secara acak yaitu dengan menuliskan nama kelompok eksperimen dan kelompok kontrol dikertas, lalu setiap guru 
mengambil satu kertas. Jika guru mendapatkan kertas kosong maka berarti kelas tersebut tidak diteliti, jika guru mendapatkan kertas dengan tulisan kelompok eksperimen maka kelasnya dijadikan sebagai kelompok yang menerapkan treatment strategi pembelajaran inkuiri. Sedangkan guru yang mendapatkan kertas dengan tulisan kelompok kontrol maka kelasnya dijadikan sebagai kelompok yang tidak menerapkan treatment. Oleh karena itu 2 dari 3 kelas populasi dijadikan sebagai sampel, berdasarkan tehnik acak maka terpilihlah 2 kelas yang terdiri dari 32 anak yaitu: 16 anak kelas Siddiq dan 16 anak kelas Ali di RA Darul Fazri.

Setelah dilakukan pengacakan peran yang bertujuan untuk menentukan kelompok eksperimen dan kelompok kontrol, maka diperoleh bahwa kelas Siddiq (B1) berperan sebagai kelompok eksperimen yang akan menggunakan strategi pembelajaran Inkuiri, dan kelas Ali (B2) berperan sebagai kelompok kontrol atau pembanding yang tidak menggunakan strategi pembelajaran Inkuiri atau menggunakan strategi pembelajaran Ekspositori,

Teknik pengumpulan data merupakan langkah yang paling strategis dalam penelitian, karena tujuan utama dari penelitian adalah mendapatkan data. Teknik pengumpulan data yang digunakan dalam penelitian ini adalah observasi terstruktur mengenai kemampuan sains anak ketika menggunakan strategi pembeljaran inkuiri. Observasi terstruktur adalah observasi yang dirancang secara sistematis tentang apa yang akan diamati, kapan dan dimana tempatnya (Sugiyono, 2013:205). Adapun instrumen yang akan digunakan pada penelitian ini yaitu: lembar observasi. Lembar observasi berisi daftar perilaku yang mungkin timbul dan akan diamati ketika anak belajar menggunakan strategi pembelajaran inkuiri. Dalam proses observasi, pengamat hanya memberi tanda centang pada kolom skor yang sesuai.

Teknik analisis data bertujuan untuk mengolah data-data yang diperoleh dari penelitian yang dilakukan sehingga akan didapat hasilnya berupa generalisasi dari pembuktian hipotesis. Teknik analisis data pada penelitian ini akan menggunakan dua statistik, yaitu analisis statistik deskriptif dan analisis statistik inferensial.

Statistik deskriptif adalah statistik yang berkenaan dengan bagaimana cara mendiskripsikan, menggambarkan, menjabarkan, atau menguraikan data yakni 1)Menentukan ukuran dari data seperti nilai modus, rata-rata dan nilai tengah (median); 2)Menentukan ukuran variabilitas data seperti, varian, tingkat penyimpangan (deviasi standar), jarak (tange); 3) menentukan ukuran bentuk data, skewness, kurtosis, plot books (Sofyan Siregar, 2016: 2). Perhitungan atau analisis statistik deskriptif pada penelitian ini menggunakan SPSS 22.0 for windows pada menu Analyze dan submenu Statistics Descriptive. 
Statistik inferensial adalah serangkaian teknik yang digunakan untuk mengkaji, menaksir dan mengambil kesimpulan berdasarkan data yang diperoleh dari dari sampel untuk menggambarkan karakteristik atau ciri dari suatu populasi. Oleh karena itu statistik inferensial disebut juga statistik induktif dan statistik penarikan kesimpulan (Sofyan Siregar, 2016: 2). Asumsi dasar dalam penggunaan analisis statistika bahwa: sampel penelitian berasal dari populasi berdistribusi normal, dan penyimpangan yang terjadi di dalam kelompok-kelompok tidak jauh berbeda. Dengan demikian, maka akan dilakukan pengujian normalitas dan homogenitas data sebelum menguji hipotesis statistik pada penelitian ini. Perhitungan atau analisis statistik inferensial pada penelitian ini menggunakan SPSS 22.0 for windows.

\section{HASIL DAN PEMBAHASAN}

\section{Kemampuan Sains Anak Kelompok B Menggunakan Strtaegi Pembelajaran Inkuiri}

Berdasarkan tehnik pengumpulan data yang telah dijelaskan sebelumnya bahwa desain dalam penelitian ini adalah quasi eksperimental dan data dalam penelitian ini akan dikumpulkan dengan tehnik observas serta lembar observasi yang telah disusun digunakan untuk mengamati kemampuan sains anak di kelompok B usia 5-6 tahun di RA Darul Fazri T.A 2018-2019 maka didapat data kemampuan sains anak sebagai berikut:

Dari hasil data pre-tets kemampuan sains awal anak pada kelas eksperimen diperoleh nilai secara keseluruhan sebanyak 64 dengan nilai terendah 2 dan nilai tertinggi 7. Kemudian memiliki nilai varian 2 dengan simpangan baku 1,4. Dengan rata-rata 4 yang dibagi dengan banyak indikator, hal ini dikategorikan bahwa kemampuan sains awal anak pada tahap belum berkembang $(\mathrm{BB})$.

Dari hasil data post-test kemampuan sains anak pada kelas eksperimen diperoleh nilai secara keseluruhan sebanyak 144 dengan nilai terendah 4 dan nilai tertinggi 12 . Kemudian rata-rata 9,0625 dan memiliki nilai varian 6,463 dengan simpangan baku 2,54214. Hal ini dikategorikan bahwa anak dikelas eksperimen terdapat pengaruh strategi pembelajaran inkuiri terhadap kemampuan sains anak pada tahap berkembang sesuai harapan (BSH). 
Tabel Distribusi Frekuensi Kemampuan Sains Anak Kelas Eksperimen (PostTest)

\begin{tabular}{|c|c|c|c|c|c|c|}
\hline \multicolumn{2}{|c|}{ Interval } & Frequency & Percent & $\begin{array}{c}\text { Valid } \\
\text { Percent }\end{array}$ & $\begin{array}{l}\text { Frequency } \\
\text { Cumulative }\end{array}$ & $\begin{array}{c}\text { Cumulative } \\
\text { Percent }\end{array}$ \\
\hline \multirow{6}{*}{ Valid } & $4-5$ & 2 & $12,5 \%$ & 12,5 & 2 & $12,5 \%$ \\
\hline & $6-7$ & 2 & $12,5 \%$ & 12,5 & 4 & $25 \%$ \\
\hline & $8-9$ & 4 & $25 \%$ & 25 & 8 & $50 \%$ \\
\hline & $10-11$ & 5 & $31,25 \%$ & 31,25 & 13 & $81,25 \%$ \\
\hline & $12-13$ & 3 & $18,75 \%$ & 18,75 & 16 & $100 \%$ \\
\hline & Total & 16 & 100 & 100 & 16 & $100 \%$ \\
\hline
\end{tabular}

Dari data tabel distribusi frekuensi di atas, terdapat peserta didik memperoleh nilai terendah sebanyak 2 orang dengan persentase $12,5 \%$ dan skor tertinggi sebanyak 3 orang dengan persentase $18,75 \%$. Untuk memperjelas hasil distribusi frekuensi di atas, maka dapat dilihat pada gambar diagram batang berikut ini:

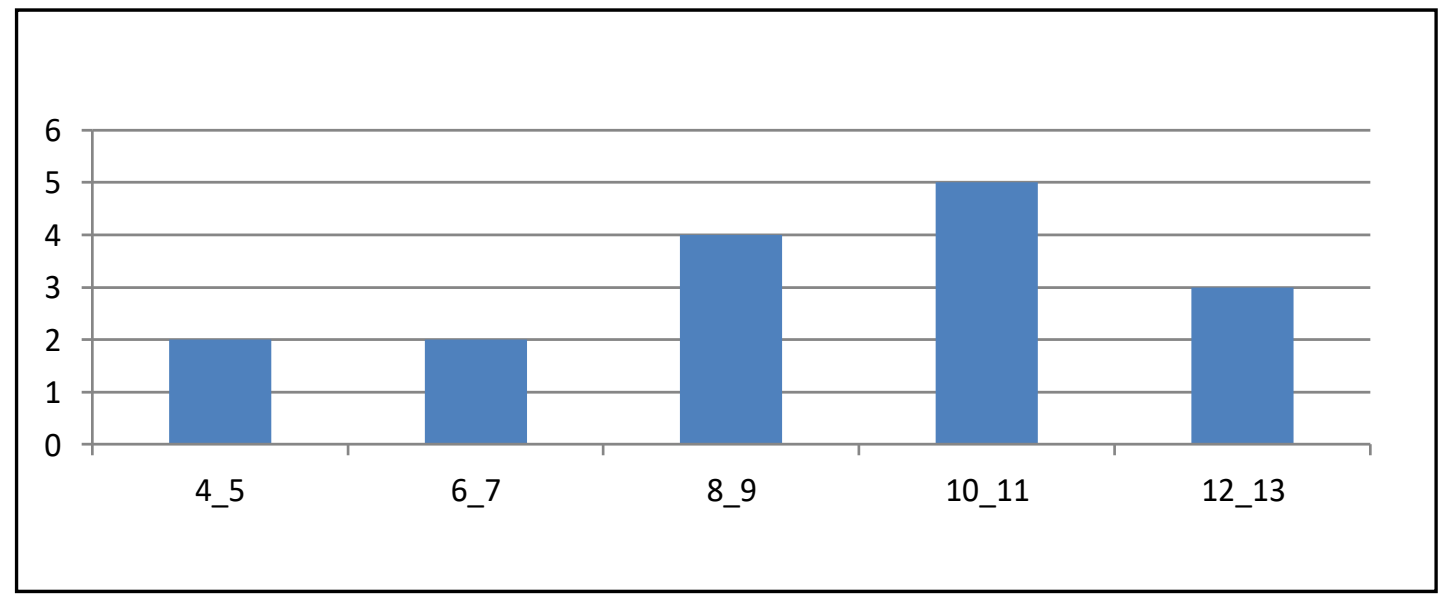

\section{Gambar Distribusi Frekuensi Data Hasil Observasi Kemampuan Sains Kelas Eksperimen (Post Test)}

\section{Kemampuan Sains Anak Kelompok B Menggunakan Strategi Pembelajaran Ekspositori}

Dari hasil data pre-tets kemampuan sains awal anak pada kelas Kontrol diperoleh nilai secara keseluruhan sebanyak 69 dengan nilai terendah 3 dan nilai tertinggi 7 . Kemudian memiliki nilai varian 1,3 dengan simpangan baku 1,1. Dengan rata-rata 4,3 yang dibagi 
dengan banyak indikator, hal ini dikategorikan bahwa kemampuan sains awal anak pada tahap belum berkembang (BB).

Sedangkan hasil data post-test kemampuan sains anak pada kelas kontrol diperoleh nilai secara keseluruhan sebanyak 92 dengan nilai terendah 4 dan nilai tertinggi 10. Kemudian secara keseluruhan memiliki nilai rata-rata 5,75 dengan simpangan baku 1,52753. Hal ini dikategorikan bahwa kemampuan sains anak di kelas kontrol mulai berkembang (MB)

Tabel Distribusi Frekuensi Kemampuan Sains Anak Kelas Eksperimen (PostTest)

\begin{tabular}{|c|c|c|c|c|c|c|}
\hline \multicolumn{2}{|c|}{ Interval } & Frequency & Percent & $\begin{array}{c}\text { Valid } \\
\text { Percent }\end{array}$ & $\begin{array}{l}\text { Frequency } \\
\text { Cumulative }\end{array}$ & $\begin{array}{c}\text { Cumulative } \\
\text { Percent }\end{array}$ \\
\hline \multirow{5}{*}{ Valid } & $4-5$ & 9 & $56,25 \%$ & 56,25 & 9 & $56,25 \%$ \\
\hline & $6-7$ & 5 & $31,25 \%$ & 31,25 & 14 & $87,5 \%$ \\
\hline & $8-9$ & 1 & $6,25 \%$ & 6,25 & 15 & $93,75 \%$ \\
\hline & $10-11$ & 1 & $6,25 \%$ & 6,25 & 16 & $100 \%$ \\
\hline & Total & 16 & 100 & 100 & 16 & $100 \%$ \\
\hline
\end{tabular}

Dari data tabel distribusi frekuensi diatas, terdapat peserta didik memperoleh nilai terendah sebanyak 9 orang dengan persentase 56,25\% dan skor tertinggi sebanyak 1orang dengan persentase $6,25 \%$. Untuk memperjelas hasil distribusi frekuensi di atas, maka dapat dilihat pada gambar diagram batang berikut ini:

\section{Pengaruh Strategi Pembelajaran Inkuiri Terhadap Kemampuan Sains Anak Kelompok B}

Setelah mendapatkan hasil dari analisis statistik deskriptif diatas, maka selanjutnya adalah melakukan uji statistik inferensial dengan tiga pengujian akni uji normaltas, uji homogenitas dan uji hipotesis.

Pada pengujian normalitas diperoleh data kelas kontrol dengan nilai $\mathrm{L}_{\text {tabel }}$ untuk $\mathrm{n}=16$ dari $\alpha=0,05$ adalah 0,213 . Dengan diperoleh $\mathrm{L}_{\text {hitung }}<\mathrm{L}_{\text {tabel }}$ maka diperoleh nilai pada kelas kontrol (pre-test) yaitu $0,020<0,213$. Kemudian pada kelas kontrol (post test) dengan nilai $0,008<0,213$. Dan nilai dikelas eksperimen (pre test) yaitu $0,009<0,213$. Serta kelas 
eksperimen (post test) yaitu 0,200<0,213. Berdasar kan nilai $\mathrm{L}_{\text {hitung }}$ pre test dan post test dari kelas kontrol dan ekperimen, masing-masing memiliki nilai $\mathrm{L}_{\text {hitung }}<\mathrm{L}_{\text {tabel, }}$, hal ini menunjukan bahwa kedua kelas tersebut memiliki Distribusi Normal.

Untuk menguji perbedaan tingkat kemampuan sains anak perlu diketahuii apakah data memenuhi asumsi sampel berasal dari varian yang homogen atau tidak, maka diperlukan uji kesamaan dua varians. Uji homogenitas observasi pada kelas eksperimen dan kelas kontrol diperoleh $\mathrm{F}_{\text {hitung }}<\mathrm{F}_{\text {tabel }}$ atau pada pre test terdapat nilai $\mathrm{F}_{\text {hitung }}=0,712$ dan pada post tets terdapat nilai $F_{\text {hitung }}=0,032$, sedangkan nilai dari $F_{\text {tabel }}$ dengan jumlah sampel adalah 16 maka $\mathrm{dk}$ pembilang= $16-1=1 \mathrm{dan} \mathrm{dk}$ penyebut $=16-1=15$. Adapun harga $F_{\text {tabel }}$ untuk dk pembilang $=15$ dan dk penyebut $=15$ adalah 2,403. Maka dapat disimpulkan bahwa varian kedua sampel pada pre test maupun post test adalah homogen.

Setelah data memenuhi persyaratan normalitas dan homogenitas, maka selanjutnya dilakukan pengujian hipotesis dengan menggunakan statistic uji-t terhadap data yang diperoleh melalui observasi awal dan observasi akhir kemampuan sains anak dari kelas eksperimen dan kelas konrol. Dari hasil perhitungan terlihat bahwa $t_{\text {hitung }}>t_{\text {tabel }}$ yaitu 4,3 > 2,042, maka disimpulkan bahwa hipotesis Ho ditolak dan Ha diterima yaitu terdapat pengaruh yang signifikan dari observasi anak kelas eksperimen.

Dalam pembelajaran sains proses pembelajaran dapat dilakukan dengan cara yang asik, unik, dan kreatif maka hendaknya pembelajaran sains dapat dilakukan dengan menggunakan strategi ataupun metode yang lebih menyenangkan dan lebih memerankan anak dalam proses belajar mengajar agar pembelajaran lebih bermakna bagi anak. Salah satu contohnya yaitu dengan menggunakan strategi pembelajaran inkuiri, anak akan merasa lebih bebas, senang dan belajar memecahkan masalah sendiri.

Berdasarkan hasil penelitian di atas, dapat disimpulkan bahwa strategi pembelajaran Inkuiri dapat mempengaruhi kemampuan sains anak. Hal ini sesuai dengan hasil penelitian Reni Devita Sari dan Sri Joeda Andajani (2017), yang menyatakan bahwa strategi Inkuiri dapat mempengaruhi kemampuan sains anak. Pembelajaran Inkuiri merupakan kegiatan yang melibatkan secara maksimal seluruh kemampuan peserta didik untuk mencari dan menyelidiki sesuatu (benda, manusia atau peristiwa) secara sistematis, kritis, logis, analitis, sehingga mereka dapat merumuskan sendiri penemuannya dengan penuh percaya diri. Proses berpikir itu sendiri dilakukan melalui tanya jawab antara guru dan peserta didik (Ali Mudrlofir dan Evi Fatimatur Rusydiyah, 2016: 66-67). Strategi pembelajaran inkuiri sangat cocok untuk di 
gunakan dalam pembelajaran sains, karena Conant dalam Khadijah mendefinisikan sains sebagai suatu deretan konsep serta skema konseptual yang berhubungan satu sama lain, yang tumbuh sebagai hasil serangkaian percobaan dan pengamatan serta dapat diamati dan di uji coba lebih lanjut (Khadijah, 2015:150).

Schlenker dalam Masganti (2016:49) juga menyatakan bahwa latihan inkuiri dapat meningkatkan pemahaman sains, produktif dalam berpikir kreatif, dan siswi menjadi terampil dalam memperoleh dan menganalisis informasi. Hal ini disebabkan karena strategi pembelajaran inkuiri berbeda dengan strategi pembelajaran lainnya, perbedaan tersebut dapat dilihat dari proses pembelajarannya yang mengharuskan anak mengolah pesan untuk mendapatkan pengetahuan, keterampilan, dan nilai-nilai.

\section{SIMPULAN}

Berdasarkan hasil penelitian di atas, maka dapat disimpulkan bahwa dapat ditarik kesimpulan sebagai berikut:

1. Kemampuan sains anak pada pre test dan post test di kelas eksperimen menggunakan strategi pembelajaran Inkuiri mengalami peningkatan hal ini dilihat dari skor nilai pre test yaitu 64 atau 33,3\% dan skor nilai post test yaitu 144 atau 75\%. Kemampuan sains anak mengalami peningkatan sebesar 98 dengan persentase $41,7 \%$.

2. Kemampuan sains anak di kelas kontrol dengan menggunakan startegi pembelajaran Ekspositori juga mengalami peningkatan pada pre test dan post tets, dengan skor nilai pre test 69 atau 35,9\% dan skor nilai post test 92 atau 47,9\%. Kemampuan sains anak mengalami peningkatan sebesar 23 dengan persentase $12 \%$.

3. Pada pre test dan post test masing-masing kelas yaitu kelas eksperimen dan kelas kontrol mengalami peningkatan. Hal ini menunjukkan bahwa kedua strategi pembelajaran yakni strategi pembelajaran Inkuiri dan strategi pembelajaran Ekspositori sama-sama memberikan pengaruh terhadap kemampuan sains anak dengan melihat hasil skor kemampuan sains yang diperoleh anak. Akan tetapi pada kelas eksperimen yakni menggunakan strategi pembelajaran Inkuiri, kemampuan sains anak mengalami peningkatan yang lebih besar. Hal ini juga dibuktikan dari hasil perhitungan uji t bahwa $t_{\text {hitung }}>t_{\text {tabel }}$ yaitu 4,3>2,42. Maka disimpulkan bahwa hipotesis Ho ditolak dan Ha diterima yaitu terdapat pengaruh yang signifikan dari strategi pembelajaran inkuiri terhadap kemampuan sains anak kelompok B di RA Darul Fazri Desa Laut Dendang. 


\section{DAFTAR PUSTAKA}

Devita Sari, Reni, dan Sri Joeda Andajani. 2017. Pengaruh Strategi Pembelajaran Inkuiri terhadap Kemampuan Sains Mengenal Hubungan Sebab Akibat pada Anak Kelompok B-TK di TK-SD Satu Atap Kedungrejo Tanjunganom Nganjuk, Jurnal: PAUD Teratai, Volume 06 Nomer 03.

Jaya, Indra. 2018. Penerapan Statistika untuk Pendidikan, Medan: Perdana Publishing.

Khadijah. 2015. Media Pembelajaran Anak Usia Dini. Medan: Perdana Publishing.

Khadijah. 2016. Pengembangan Kognitif Anak Usia Dini, Medan: Perdana Publishing.

Masganti, Dkk. 2016. Pengembangan Kreativitas Anak Usia Dini, Medan: Perdana Publishing,

Menteri Pendidikan dan Kebudayaan. 2014. Peraturan menteri Pendidikan dan Kebudayaan Republik Indonesia Nomor 137 Tahun 2014 Tentang Standar nasional Pendidikan Anak Usia Dini, Jakarta: Menteri Pendidikan dan Kebudayaan RI.

Mirawati dan Rini Nugraha. 2017. Meningkatkan Keterampilan Proses Sains Anak Usia Dini Melalui Aktivitas Berkebun. Jurnal Pendidikan: Vol 1 No 1.

Mudrlofir, Ali dan Evi Fatimatur Rusydiyah. 2016. Desain Pembelajaran Inovatif. Jakarta: Raja Grafindo Persada.

Nurhafizah. 2017. Strategi Pengembangan Kemampuan Sains Anak Taman Kanak-Kanak Di Koto Tangah Padang, Jurnal Anak Usia Dini dan Pendidikan Anak Usia Dini: Vol 3 No 3b Desember.

Nugraha, Ali. 2008. Pengembangan Pembelajaran Sains Pada Anak Usia Dini. Bandung: JILSI Foundation.

Rohani, (Editor: Asrul dan Ahmad Syukri Sitorus). 2016. Strategi Pendidikan Anak Usia Dini Dalam Membina Sumber Daya Manusia Berkarakter, Medan:Perdana Publishing.

Sugiyono. 2013. Metode Penelitian Pendidikan Pendekatan Kuantitatif, Kualitattif dan R\&D, Bandung: Alfabeta.

Siregar, Syofyan. 2016. Statistika Deskriptif Untuk Penelitian, Jakarta: Raja Grafindo Persada. 